\title{
Myocyte Death in Streptozotocin-Induced Diabetes in Rats Is Angiotensin II- Dependent
}

\author{
Fabio Fiordaliso, Baosheng Li, Roberto Latini, Edmund H. Sonnenblick, \\ Piero Anversa, Annarosa Leri, and Jan Kajstura
}

Department of Medicine (FF, BL, EHS, PA, AL, JK), New York Medical College, Valhalla, New York; Istituto di Ricerche Farmacologiche Mario Negri (RL), Milano, Italy

SUMMARY: To determine whether myocyte death and angiotensin II (AT II) formation are implicated in the development of diabetic cardiomyopathy, rats were injected with streptozotocin, and apoptosis and necrosis were measured at 3,10 , and 28 days. Expression of the components of the renin-angiotensin system (RAS) and AT II levels were assessed at 3 days. The percentage of AT II-labeled myocytes and the number and distribution of AT II sites in myocytes were measured at 3 and 10 days. The effects of $\mathrm{AT}_{1}$ blockade on local RAS and cell death were examined at 3 days. Diabetes was characterized by myocyte apoptosis that peaked at 3 days and decreased at 10 and 28 days, in spite of high concentrations of blood glucose. Cell necrosis was absent throughout. Angiotensinogen, renin, and $\mathrm{AT}_{1}$ receptor increased in myocytes from diabetic rat hearts, while angiotensin-converting enzyme and $\mathrm{AT}_{2}$ remained constant. AT II quantity increased severalfold, as did the fraction of AT II positive cells and the number of AT II sites per myocyte. However, AT II labeling decreased at 10 days, which paralleled the reduction in myocyte death. $\mathrm{AT}_{1}$ antagonist inhibited upregulation of this receptor and angiotensinogen, which prevented $A T$ II synthesis and myocyte death at their peaks with diabetes. An aggregate 30\% myocyte loss and a $14 \%$ increase in the volume of viable cells were found in diabetic rats at 28 days. Thus diabetic cardiomyopathy may be viewed as an AT II-dependent process in which that peptide plays a critical role in myocyte death and hypertrophy. (Lab Invest 2000, 80:513-527).

$D$ iabetes is characterized by the development of a cardiac myopathy that is independent from intercurrent coronary pathologic conditions (Bell, 1995; Rodrigues and McNeill, 1992). Diastolic dysfunction is a typical hemodynamic alteration of diabetes (Fein and Sonnenblick, 1985), which also leads to multiple biochemical abnormalities of the contractile apparatus. Reduced actomyosin and actin-activated myosin ATP-ase activities are invariably present, and these modifications are associated with a shift from the $V_{1}$ predominant myosin isoform to the $\mathrm{V}_{3}$ isoenzyme (Malhotra et al, 1981; Pierce and Dhalla, 1981). Recently, protein kinase $\mathrm{C}$ (PKC)- $\epsilon$ has been implicated in the phosphorylation of the regulatory protein troponin I, which possibly decreases myofilament $\mathrm{Ca}^{2+}$ sensitivity and force generation of the myocardium (Malhotra et al, 1997). However, these and other findings documenting metabolic disturbances (Rodrigues et al, 1998) and vascular defects (Hardin, 1996) have left unanswered the question of whether those disturbances play a primary or secondary role in the occurrence of a diabetic myopathy. Experimentally, streptozotocin (STZ)-induced diabetes is associated with a reduction in cardiac mass over time that remains unexplained. Whether myocyte atrophy, cell loss, or both contribute to the decrease in healthy

Received November 17, 1999.

This work was supported by grants HL-38132, HL-39902, HL-43023 and $A G-15756$.

Address reprint requests to: Dr. J. Kajstura, Department of Medicine, Vosburgh Pavilion, Room 302A, Valhalla, New York 10595. Fax: $914-$ 594-4406; E-mail: jankajstura@nymc.edu myocardium and relative ventricular dilation is a critical issue. Changes in myocardial loading with diabetes are minimal (Fein and Sonnenblick, 1985), which indicates that hemodynamic factors are not implicated in myocyte atrophy. Conversely, inhibition of the local RAS interferes with activation of PKC- $\epsilon$ and troponin I phosphorylation (Malhotra et al, 1997), which suggests that the myocyte RAS is upregulated in diabetes. AT II release in the myocardium may trigger the endogenous cell death pathway (Li et al, 1997a, Tanimura et al, 1999) and may promote cellular hypertrophy as well (Rockman et al, 1994). These possibilities are supported by in vitro results obtained after the addition of AT II to cultures of ventricular myocytes (Kajstura et al, 1997; Liu et al, 1998). Therefore, the effects of diabetes on ongoing myocyte death by apoptosis and necrosis were examined in the early and established phases of the disease in an attempt to characterize the onset and development of the cardiac myopathy. The upregulation of the local RAS, which led to the formation of AT II in myocytes, was determined at the peak of cell death in rats with diabetes. Similarly, the impact of $A T_{1}$ receptor blocker on myocyte death was evaluated, and the changes in cell size and number in the left ventricular myocardium over a period of 4 weeks were measured in diabetic rats.

\section{Results}

\section{Animals and Blood Glucose}

Rats injected with vehicle only (the control group) or with STZ were examined at 3,10 , and 28 days; $n$ 
Table 1. Effects of Diabetes on Cardiac Function

\begin{tabular}{|c|c|c|c|}
\hline & $\begin{array}{l}\text { Control } \\
(n=10)\end{array}$ & $\begin{array}{l}\text { Control pair-fed } \\
\qquad(\mathrm{n}=8)\end{array}$ & $\begin{array}{l}\text { Diabetes } \\
(n=10)\end{array}$ \\
\hline Heart rate (bpm) & $339 \pm 46$ & $359 \pm 47$ & $364 \pm 57$ \\
\hline Systolic blood pressure $(\mathrm{mm} \mathrm{Hg})$ & $102 \pm 16$ & $92 \pm 12$ & $88 \pm 8$ \\
\hline Diastolic blood pressure (mm Hg) & $62 \pm 15$ & $57 \pm 17$ & $61 \pm 9$ \\
\hline Mean blood pressure $(\mathrm{mm} \mathrm{Hg})$ & $75 \pm 15$ & $69 \pm 15$ & $70 \pm 8$ \\
\hline LV end diastolic pressure $(\mathrm{mm} \mathrm{Hg})$ & $2.4 \pm 2.9$ & $6.9 \pm 6.8$ & $4.6 \pm 2.3$ \\
\hline LV systolic pressure $(\mathrm{mm} \mathrm{Hg})$ & $105 \pm 14$ & $93 \pm 11$ & $92 \pm 13$ \\
\hline LV developed pressure (mm Hg) & $102 \pm 13$ & $86 \pm 6^{*}$ & $88 \pm 13^{\star}$ \\
\hline $\mathrm{LV}+\mathrm{dP} / \mathrm{dt}(\mathrm{mm} \mathrm{Hg} / \mathrm{s})$ & $9260 \pm 2143$ & $7350 \pm 1135$ & $6932 \pm 1417^{*}$ \\
\hline LV-dP/dt $(\mathrm{mm} \mathrm{Hg} / \mathrm{s})$ & $7300 \pm 1521$ & $5740 \pm 913^{*}$ & $5224 \pm 782^{\star}$ \\
\hline Central venous pressure (mm $\mathrm{Hg})$ & $2.6 \pm 2.4$ & $2.1 \pm 1.2$ & $3.7 \pm 2.4$ \\
\hline RV end diastolic pressure (mm Hg) & $3.2 \pm 2.2$ & $2.9 \pm 1.2$ & $4.5 \pm 2.2$ \\
\hline RV systolic pressure (mm $\mathrm{Hg})$ & $29.5 \pm 3$ & $24.5 \pm 2.3^{*}$ & $28.2 \pm 4.9$ \\
\hline RV developed pressure (mm Hg) & $26.3 \pm 3.8$ & $21.6 \pm 1.6^{\star}$ & $23.8 \pm 3.7$ \\
\hline $\mathrm{RV}+\mathrm{dP} / \mathrm{dt}(\mathrm{mm} \mathrm{Hg} / \mathrm{s})$ & $3802 \pm 787$ & $2953 \pm 655$ & $3099 \pm 597$ \\
\hline $\mathrm{RV}-\mathrm{dP} / \mathrm{dt}(\mathrm{mm} \mathrm{Hg} / \mathrm{s})^{\prime}$ & $2755 \pm 690$ & $1984 \pm 486^{*}$ & $1900 \pm 399^{*}$ \\
\hline
\end{tabular}

Results are presented as mean $\pm \mathrm{SD}$. LV, left ventricle; RV, right ventricle; $+\mathrm{dP} / \mathrm{dt}$, rate of pressure rise; $-\mathrm{dP} / \mathrm{dt}$, rate of pressure decay.

* Indicates a significant difference from control value.

values for controls were 18,4 , and 23 , respectively. Corresponding values for STZ-treated animals were 19, 8, and 10. Controls at 3 and 10 days consisted only of pair-fed rats. At 28 days, 15 control animals were not pair-fed, but an additional group of 8 pair-fed rats was included. The effects of losartan on STZinjected rats $(n=16)$ were evaluated at 3 days, because (as described below) myocyte death peaked at this interval. Losartan was given at $0.25 \mathrm{gm} / \mathrm{L}$ in the drinking water; this corresponded to a daily dose of 46 $\mathrm{mg} / \mathrm{kg}$ body weight. Blood glucose levels in control rats were comparable at $1,3,10$, and 28 days. These values were combined and averaged to $6.1 \pm 2.2$ mmole/L. In diabetic rats, glucose concentrations were $24.5 \pm 3.1,26.1 \pm 2.7,27.5 \pm 0.8$, and $29.6 \pm$ $2.3 \mathrm{mmole} / \mathrm{L}$ at $1,3,10$, and 28 days following STZ administration, respectively. The value in losartantreated diabetic rats was $26.6 \pm 2.9 \mathrm{mmole} / \mathrm{L}$.

\section{Cardiac Function}

Left and right ventricular function in nondiabetic, nondiabetic pair-fed, and diabetic rats at 28 days is listed in Table 1. Diabetes was characterized by a decrease in left ventricular developed pressure, left ventricular

Table 2. Effects of Diabetes on Body and Cardiac Weights

\begin{tabular}{lrcc}
\hline & $\begin{array}{c}\text { Control } \\
(\mathrm{n}=15)\end{array}$ & $\begin{array}{c}\text { Control } \\
\text { pair-fed } \\
(\mathrm{n}=8)\end{array}$ & $\begin{array}{c}\text { Diabetes } \\
(\mathrm{n}=10)\end{array}$ \\
\hline Body weight $(\mathrm{gm})$ & $447 \pm 30$ & $305 \pm 20^{*}$ & $315 \pm 42^{*}$ \\
Heart weight $(\mathrm{mg})$ & $1058 \pm 84$ & $807 \pm 68^{*}$ & $839 \pm 103^{*}$ \\
LV weight $(\mathrm{mg})$ & $812 \pm 81$ & $635 \pm 60^{*}$ & $646 \pm 78^{*}$ \\
RV weight $(\mathrm{mg})$ & $246 \pm 28$ & $172 \pm 13^{*}$ & $192 \pm 31^{*}$ \\
\hline
\end{tabular}

Results are presented as mean $\pm \mathrm{SD}$. LV, left ventricle; RV, right ventricle.

* Indicates a significant difference from control values. rate of pressure rise $+\mathrm{dP} / \mathrm{dt}$, and left and right ventricular rate of pressure decay, $-\mathrm{dP} / \mathrm{dt}$. With the exception of $+\mathrm{dP} / \mathrm{dt}$, similar changes were seen in nondiabetic pair-fed controls. Moreover, right ventricular systolic and developed pressures were reduced in pair-fed animals. Heart function was not altered at 3 and 10 days after STZ administration. Treatment of diabetic rats with losartan for 3 days did not modify ventricular hemodynamics (not shown). In summary, diabetes and severe restriction in food led to a modest depression in cardiac performance.

\section{Cardiac Weights}

Body weight and the weights of the heart, left ventricle, and right ventricle were comparable in control pair-fed and diabetic rats at 3 and 10 days after STZ administration (data not shown). Table 2 lists these parameters in animals at 28 days. Body weight and ventricular weights were greater in controls than in pair-fed and diabetic rats. Minimal differences existed between pair-fed and diabetic rats, but they did not reach statistical significance. In summary, diabetes and food restriction chronically decreased heart weight and body weight.

\section{Myocyte Death}

Myocyte apoptosis was measured by two independent methods consisting of terminal deoxynucleotidyl transferase (TdT) and hairpin oligonucleotide probes. The TdT assay identifies staggered ends of the deoxyribonucleic acid (DNA) with one or more (up to four bases) 3' overhangs. This type of reaction reflects DNA damage produced by $\mathrm{Ca}^{2+}$-dependent deoxyribonuclease (DNase) I and pH-dependent DNase II (Anversa et al, 1998). However, this technique does not distinguish the effects of these two DNases. Conversely, apoptosis mediated by activation of 
$\mathrm{Ca}^{2+}$-dependent DNase I can be detected by the recognition of single base $3^{\prime}$ overhangs, which occur only through the induction of this endonuclease. This can be achieved with the use of a biotin-labeled oligonucleotide probe for identification of doublestrand breaks (Didenko and Hornsby, 1996; Didenko et al, 1998). This probe is hairpin designed; the terminus of the stem has a single $3^{\prime} \mathrm{A}$ overhang. The oligonucleotide lacks a $5^{\prime}$ phosphate, and this characteristic does not allow the ligation of the probe to $3^{\prime}$ hydroxyls on the ends of single-strand DNA fragments. A similar hairpin- designed probe, characterized by blunt DNA ends, was prepared and applied for the detection of double-strand cleavage of the DNA with blunt ends (Didenko et al, 1998). Such a form of DNA damage corresponds to cell necrosis (Anversa et al, 1998), which has been confirmed by an additional independent method (Li et al, 1999).

Myocyte apoptosis, necrosis, and apoptosisnecrosis in the left ventricle were measured at 3, 10, and 28 days after STZ administration. An identical analysis was performed in control hearts from nonpair-fed and pair-fed rats. Examples of labeling of myocyte nuclei by TdT and hairpin probe with $3^{\prime}$ overhang are shown by confocal microscopy (Figures 1 and 2). Myocytes were not stained by the hairpin with blunt DNA ends in any of the animals, although numerous myocytes were labeled by this probe in an infarcted myocardium. One-day-old myocardial infarcts were used as positive controls for cell necrosis (not shown).

Figure 3 illustrates the extent of myocyte apoptosis assessed by TdT and hairpin probe at the three time intervals after STZ injection. Diabetes resulted in an average 13.0-fold ( $p<0.001$ ), 8.0-fold ( $p<0.001$ ), and 3.6-fold ( $p<0.005)$ increase in cell death at 3, 10, and 28 days, respectively. Myocyte apoptosis was low in all control groups, and none of the small differences was statistically significant. Food restriction did not affect the degree of ongoing cell death in the myocardium. It is important to note that from 3 to 10 days there was a $36 \%$ decrease in apoptosis in rats with diabetes, and this decline was significant $(p<0.005)$. Similarly, the $78 \%$ reduction in myocyte apoptosis in diabetic rats from 3 to 28 days was significant $(p<$ 0.001). In summary, starvation had no effect on the various aspects of cell death in the heart, while diabetes was coupled with the activation of myocyte apoptosis in the absence of cell necrosis.

\section{Myocyte Size and Number}

The decrease in left ventricular weight in rats with diabetes at 28 days was associated with chronic apoptotic myocyte death, which may have accounted in part for the reduction in cardiac mass. However, the evaluation of cell death at various intervals does not allow the computation of the overall loss of cells in the ventricle, because the time required for the completion of myocyte apoptosis is currently unknown. Even more complex was the understanding of the alteration in cardiac weight in pair-fed rats in which cell death was absent or negligible. For this purpose, the changes in myocyte volume and number were measured by means of the morphometric approach described in the Methods section.

Figure 4 illustrates that myocyte volume in diabetic rats was $14 \%(p<0.001)$ and $44 \%(p<0.001)$ larger than in control nonpair-fed and pair-fed animals, respectively. By contrast, food restriction was associated with a $21 \%(p<0.001)$ reduction in myocyte size. The aggregate number of myocytes in the left ventricle decreased $30 \%(p<0.001)$ in rats with diabetes. Conversely, myocyte number in rats subjected to starvation remained constant. The changes in myocyte size and number in rats with diabetes and cellular atrophy in food-restricted rats were not associated with alterations in the volume fraction of myocytes (control nonpair-fed $=85 \pm 2 \%$, control pairfed $=84 \pm 1 \%$, diabetic $=85 \pm 2 \%$ ) or the interstitium (control nonpair-fed $=15 \pm 2 \%$, control pair-fed $=16 \pm 1 \%$, diabetic $=15 \pm 2 \%$ ) in the myocardium. In summary, myocyte loss and inadequate reactive hypertrophy of the remaining cells were responsible for the reduction in heart weight in rats with diabetes, while myocyte atrophy alone decreased cardiac mass in rats subjected to food restriction.

\section{Diabetes and the Local RAS}

To evaluate whether hyperglycemia resulted in an upregulation of the myocyte RAS, the expression of angiotensinogen (Aogen), renin, angiotensinconverting enzyme (ACE), and $A T_{1}$ and $A T_{2}$ receptors in myocytes was evaluated at 3 days after the administration of STZ. This was done because AT II formation may be enhanced in diabetes. (Malhotra et al, 1997; Zuanetti et al, 1997) Myocyte apoptosis was higher at 3 days than at 10 and 28 days after STZ administration. The effects of losartan on the activation of RAS in diabetic rats was also assessed. Figure $5 \mathrm{~A}$ illustrates that the quantity of Aogen, represented by optical density (OD) units, increased 3.8-fold in rats with diabetes and that losartan reduced this response by $80 \%$ (control $=1.58 \pm 0.40, n=6$; diabetes $=$ $6.02 \pm 0.84, n=6, p<0.001$; diabetes + losartan $=$ $1.22 \pm 0.41, n=6, p<0.001)$. The renin amount (Figure 5B) was also upregulated by the pathologic state, and the $A T_{1}$ blocker did not decrease this reaction (control $=1.28 \pm 0.34, n=6$; diabetes $=$ $2.84 \pm 0.52, n=6, p<0.001$; diabetes + losartan $=$ $2.61 \pm 0.45, n=6, p<0.001)$. ACE expression (Figure 5C) was not influenced by diabetes or losartan administration (control $=1.40 \pm 0.19, n=6$; diabetes $=1.65 \pm 0.30, n=6, p=0.2$; diabetes + losartan $=1.52 \pm 0.16, n=6, p=0.6)$. Moreover, the $30 \%$ increase in $\mathrm{AT}_{2}$ quantity after STZ administration (Figure 5D) was not significant (control $=1.15 \pm 0.27$, $n=6$; diabetes $=1.49 \pm 0.49, n=6, p=0.4$ diabetes + losartan $=1.41 \pm 0.26, n=6, p=0.8)$. In contrast, $\mathrm{AT}_{1}$ (Figure 5E) increased 2.4-fold with diabetes, but losartan decreased this effect by $65 \%$ (control $=1.61 \pm 0.32, n=6$; diabetes $=3.88 \pm 0.49$, $n=6, p<0.001 ;$ diabetes + losartan $=1.36 \pm 0.48$, 

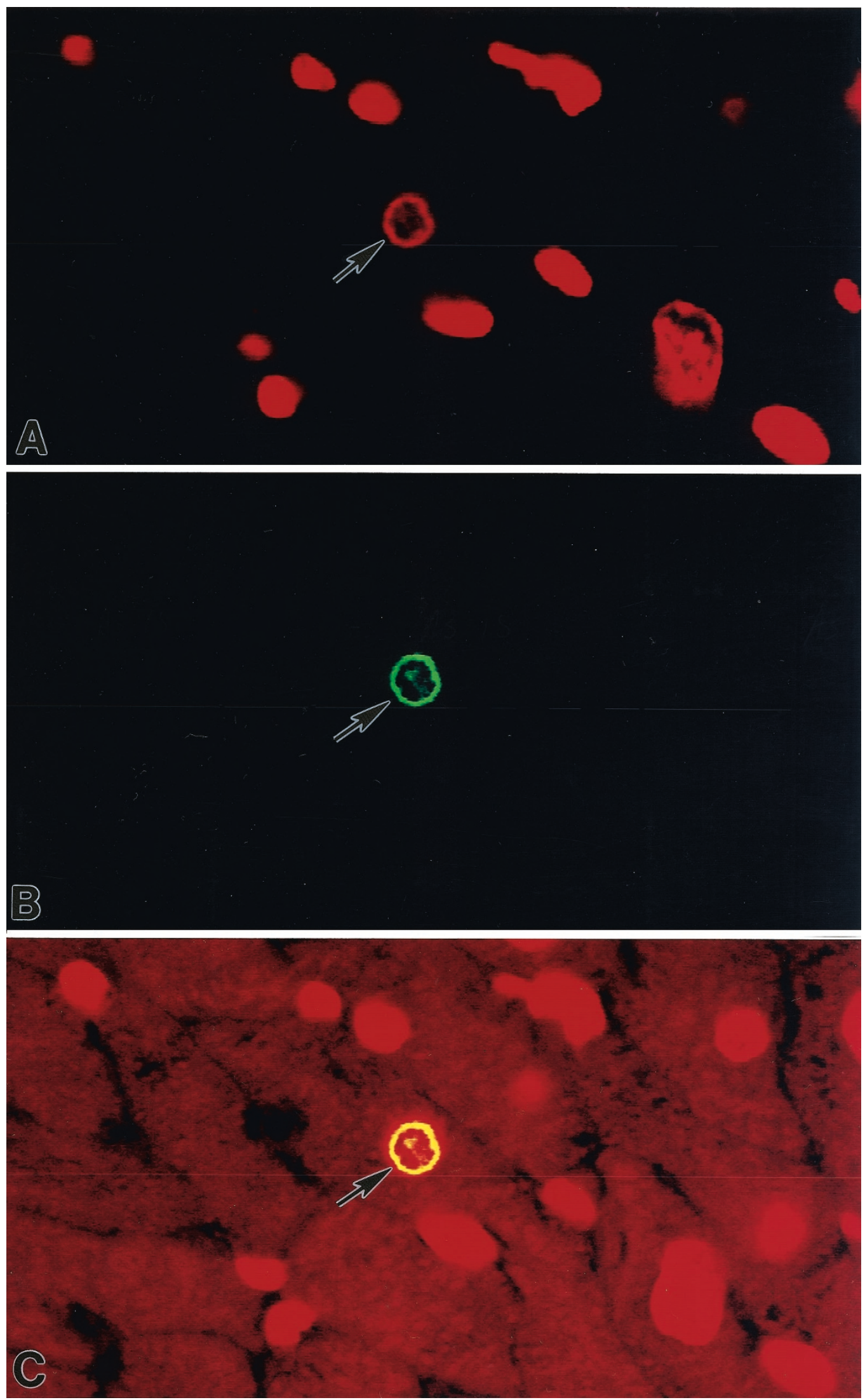

Figure 1.

Chromatin margination and loss of deoxyribonucleic acid (DNA) (arrow) are shown by red fluorescence of propidium iodide (PI) in Panel A, green fluorescence (arrow) demonstrates double-strand DNA cleavage by terminal deoxynucleotidyl transferase (TdT) in Panel B, and myocyte cytoplasm is shown by the red fluorescence of $\alpha$-sarcomeric actin in panel C. Yellow fluorescence of the nucleus (arrow) represents the combination of PI and TdT labeling. Confocal microscopy, $\times 800$. 

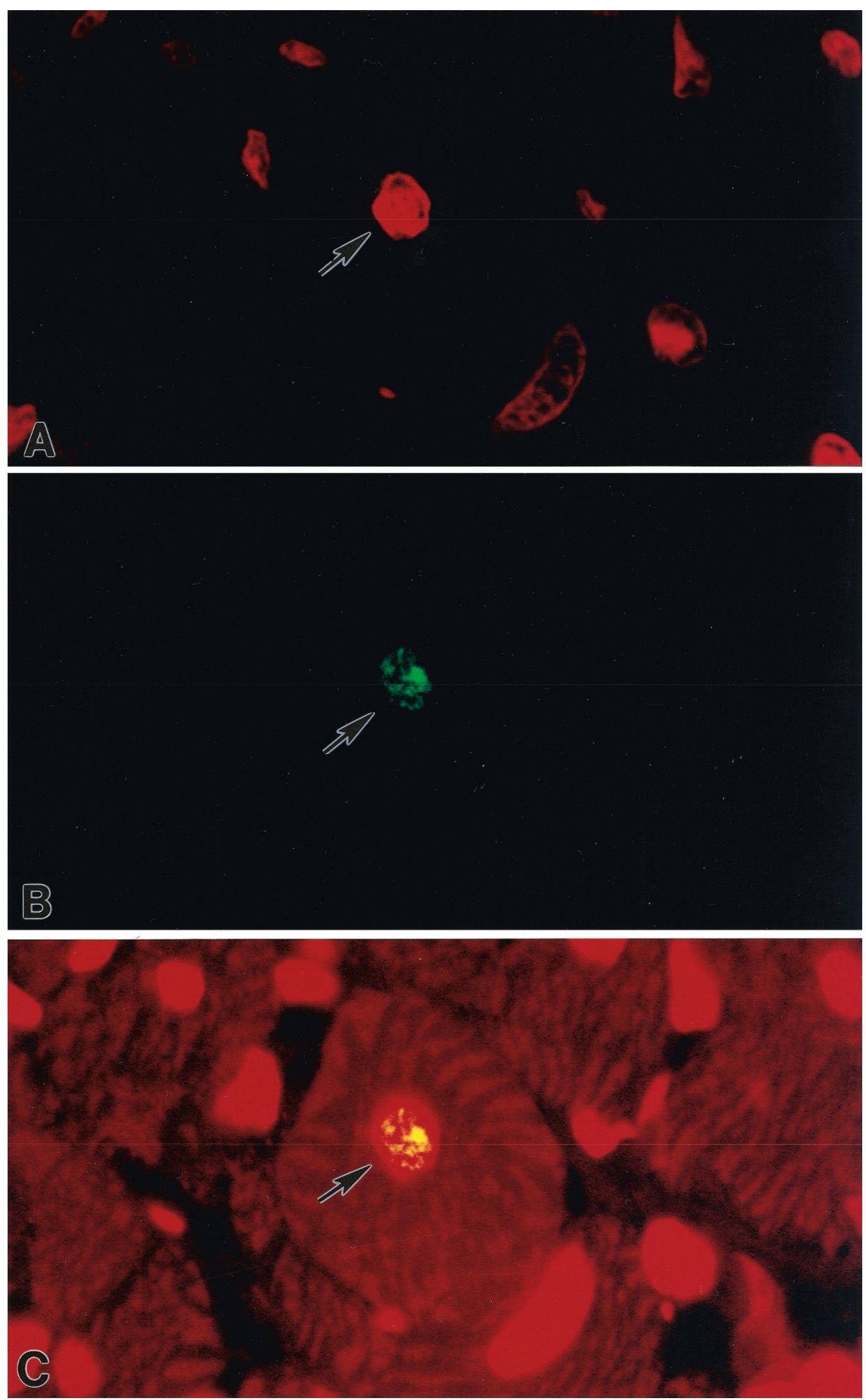

\section{Figure 2.}

Chromatin condensation and initial margination (arrow) are shown by red fluorescence of PI in Panel A, green fluorescence (arrow) demonstrates double-strand DNA cleavage by hairpin probe in Panel $\mathrm{B}$, and myocyte cytoplasm is shown by red fluorescence of $\alpha$-sarcomeric actin in panel C. Yellow fluorescence of the nucleus (arrow) represents the combination of PI and hairpin labeling. Confocal microscopy, $\times 1200$. 

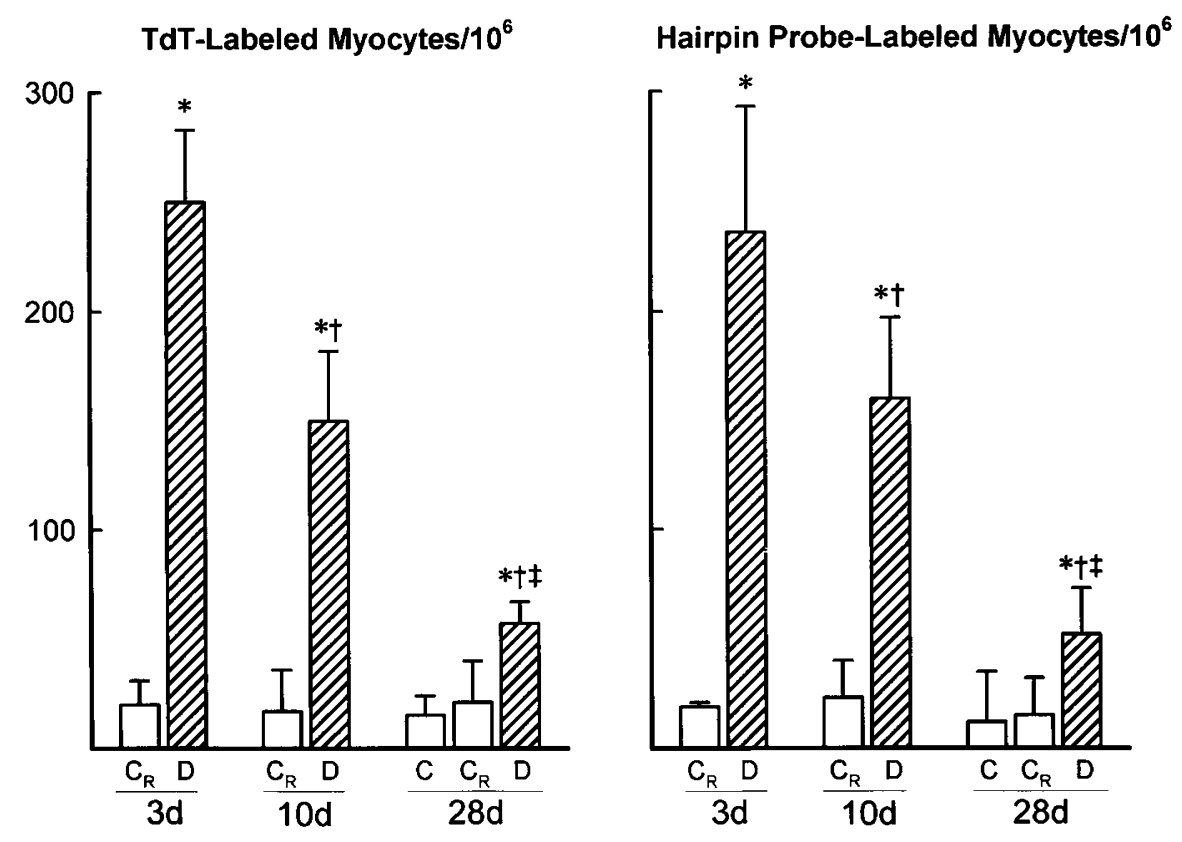

Figure 3.

The effects of diabetes on myocyte apoptosis is measured by TdT and hairpin assays. Results are mean \pm SD. * Indicates a difference from control rats, ${ }^{t}$ indicates a difference from the value at 3 days, and findicates a difference from the value at 10 days. $C_{R}$, control rats on a restricted diet; $C$, control rats on a nonrestricted diet; D, diabetic rats; d, days. $\mathrm{C}_{\mathrm{R}}: n=6$ (3 days), 4 (10 days), and 8 (28 days); C: $n=15$ (28 days); D: $n=6$ (3 days), 8 (10 days), and 10 (28 days).

A

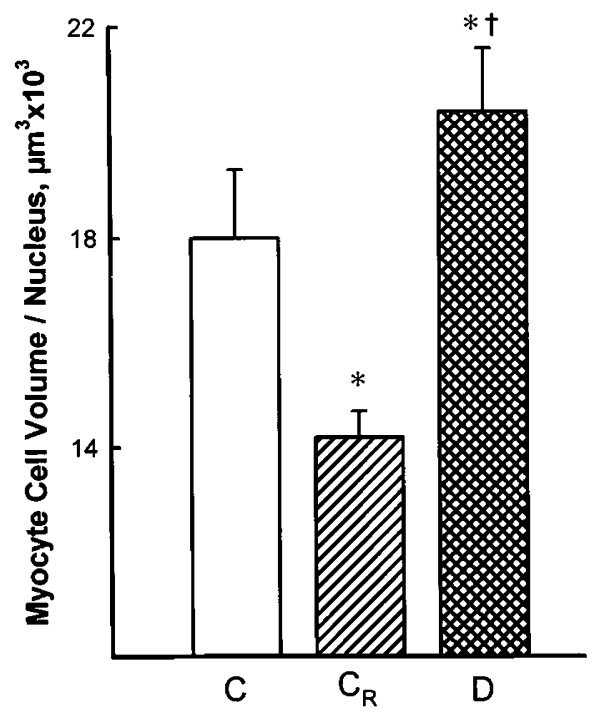

B

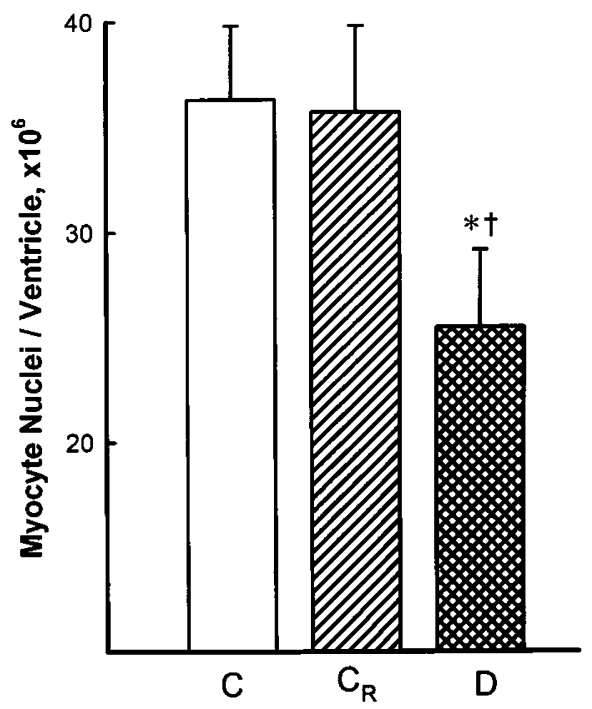

Figure 4.

The effects of 28 days of diabetes on the myocyte volume per nucleus $(A)$ and on the number of left ventricular myocyte nuclei (B). Results are mean \pm SD. ${ }^{\star}$ Indicates a difference from control rats on a nonrestricted diet $(C)$, tindicates a difference from control rats on a restricted diet $\left(C_{R}\right)$. D, diabetic rats. C: $n=15, C_{\mathrm{R}}: n=8$, D: $n=10$.

$n=6, p<0.001)$. In summary, diabetes upregulated Aogen, renin, and $\mathrm{AT}_{1}$ in myocytes, but Aogen and $\mathrm{AT}_{1}$ were attenuated by losartan.

\section{AT II Formation, AT, Receptor Blocker, and Myocyte Apoptosis in Diabetes}

The synthesis of AT II in myocytes at 3 days after STZ administration was measured by ELISA (Figure 6). The amount of AT II per milligram of myocyte protein was 14-fold higher in diabetic rats than in controls, and this difference was statistically significant $(p<0.001)$. Losartan prevented this change. Similarly, the percentage of myocytes labeled by AT II antibody (Figures 7A-7D) nearly doubled in rats with diabetes, whereas the $A T_{1}$ blocker inhibited this phenomenon almost completely (Figure 8A). Moreover, the number of AT II-positive sites per square millimeter of myocytes increased 7.5 -fold $(p<0.001)$ in diabetic 
A

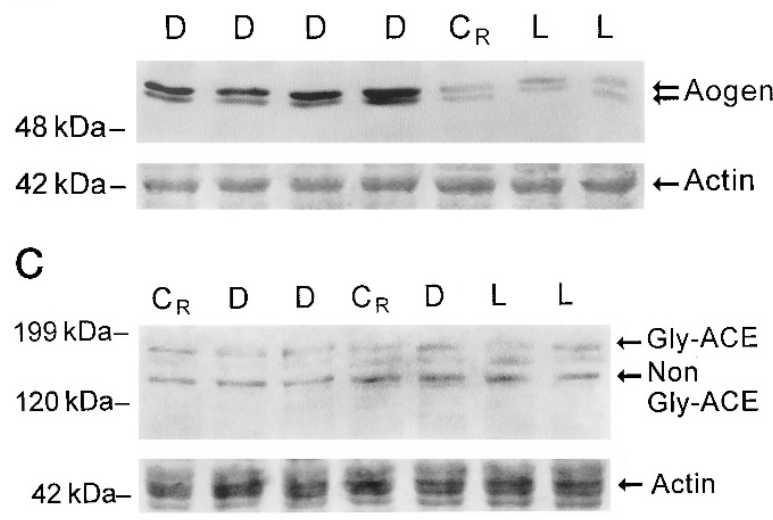

B

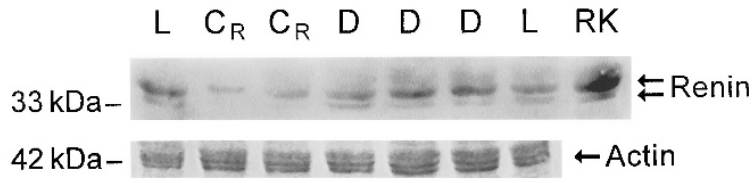

$\begin{array}{lllllllllll}D & C_{R} & C_{R} & D & D & D & L\end{array}$

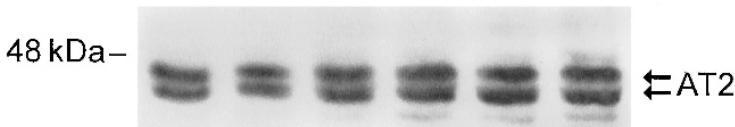

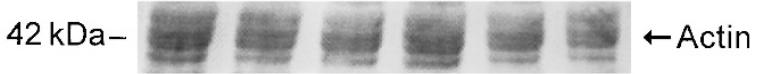

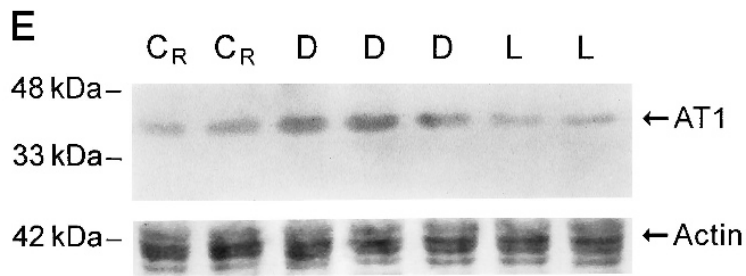

\section{Figure 5.}

The effects of 3 days of diabetes and treatment with losartan on the expression of Aogen (A), renin (B), angiotensin-converting enzyme (ACE) (C), $A T_{2}$ (D), and AT (E) in left ventricular myocytes measured by Western blot. $C_{R}$, control rats on a restricted diet; D, diabetic rats; $L$, diabetic rats treated with losartan; RK, rat kidney. Lower panels: Loading conditions by Ponceau Red staining of transferred proteins.

rats but increased only $57 \%$ in diabetic rats treated with losartan (Figure 8B). This latter change was not significant $(p=0.58)$. The distribution of AT II sites in labeled cells is shown in Figure 8C. In comparison with controls, the number of AT II dots increased markedly in the heart of diabetic rats. In the presence of losartan, this parameter was similar to that found in the normal rat heart.

To document whether the enhanced synthesis of AT II in myocytes in rats with diabetes at 3 days decreased with time, an analysis identical to that described above was performed in pair-fed control and diabetic rats at 10 days. Diabetes was associated with a $20 \%(p<0.05)$ increase in the fraction of AT II positive myocytes, from $23.8 \pm 2.4 \%$ to $28.6 \pm 3.1 \%$, and a 3.9-fold $(p<0.002)$ increase in the number of AT II sites in the cells, from $1738 \pm 299$ to $6816 \pm$ $1775 / \mathrm{mm}^{2}$ myocytes. The distribution of AT II sites in positive myocytes showed a pattern similar to that illustrated in Figure $8 \mathrm{C}$ but with significantly lower values throughout (not shown).

Finally, the treatment of rats with losartan significantly reduced the extent of apoptosis associated with STZ-induced diabetes at 3 days. In the presence of the $\mathrm{AT}_{1}$ blocker, apoptosis was essentially similar in control pair-fed and diabetic rats (control: TdT $=20 \pm$ $11 / 10^{6}, n=6$; hairpin probe $=19 \pm 12 / 10^{6}, n=6$; diabetes: $\mathrm{TdT}=250 \pm 30 / 10^{6}, n=6, p<0.001$; hairpin probe $=236 \pm 57 / 10^{6}, n=6, p<0.001$; diabetes + losartan: $\operatorname{TdT}=41 \pm 15 / 10^{6}, n=8, p<$ 0.001 versus diabetes, $p=0.23$ versus control; hairpin probe $=44 \pm 10 / 10^{6}, n=8, p<0.001$ versus

\section{Ang II Concentration in Myocytes}

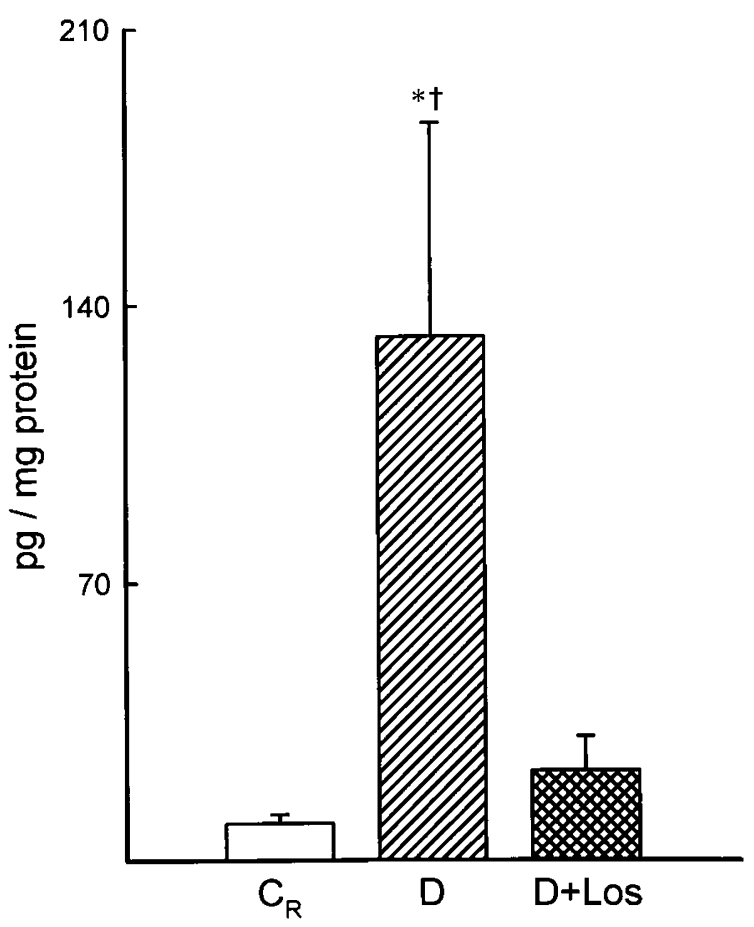

Figure 6.

The effects of 3 days of diabetes and treatment with losartan on AT II concentration. Results are presented as mean $\pm \mathrm{sD} .{ }^{*}$ Indicates a difference from control rats on a restricted diet $\left(C_{R}\right)$, indicates a difference from diabetic rats treated with losartan $(\mathrm{D}+\mathrm{Los})$. D, diabetic rats. $\mathrm{C}_{\mathrm{R}}: n=6, \mathrm{D}: n=6$, D+Los: $n=6$. 

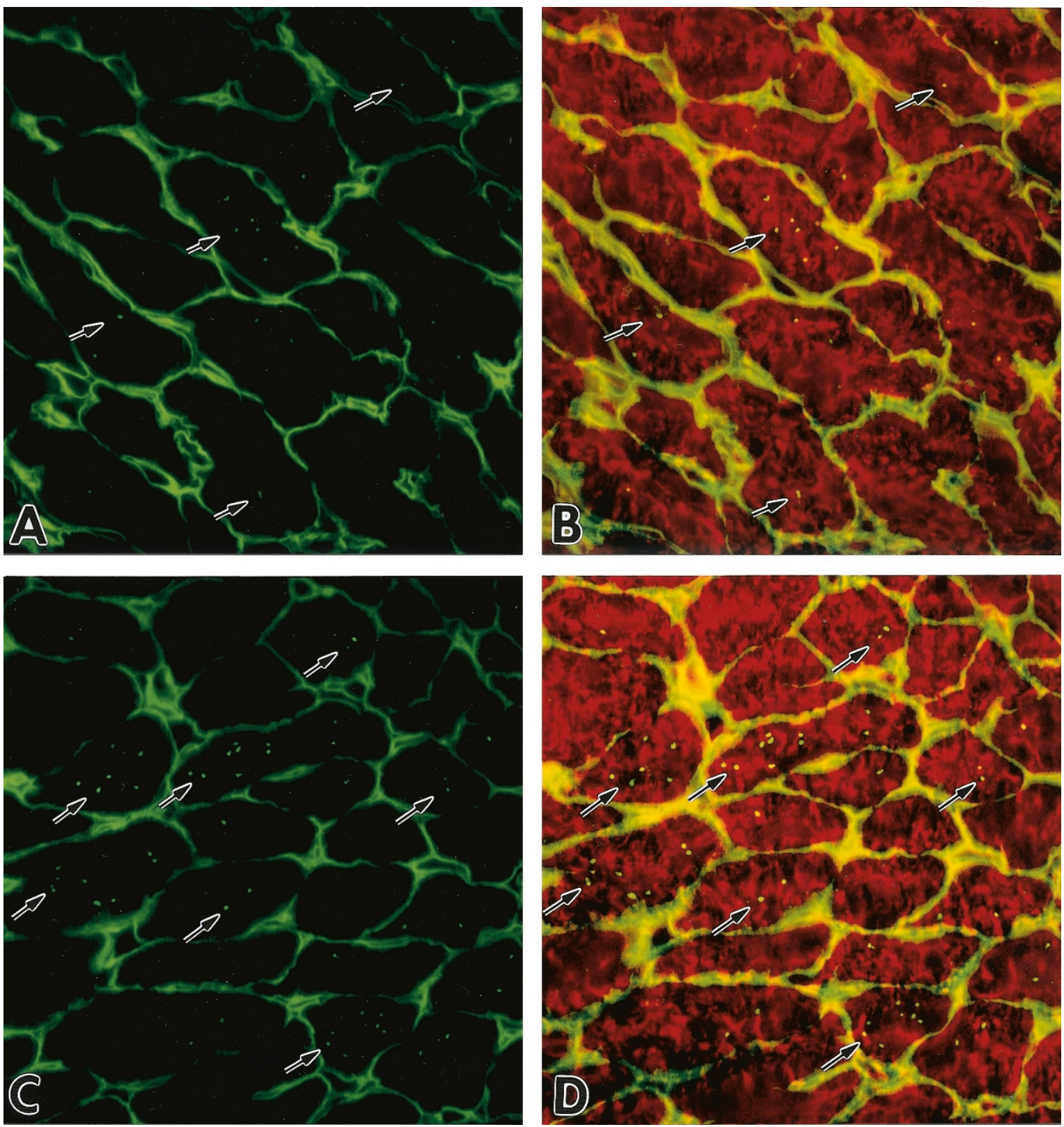

\section{Figure 7.}

AT II localization in myocytes of control ( $A$ and $B$ ) and diabetic ( $C$ and D) rats. The green fluorescent dots in panels A and C show AT II sites (arrows); myocyte profiles are identified by laminin staining, which is also depicted by green fluorescence. Panels B and D illustrate the same staining shown in panels A and $C$ in combination with $\alpha$-sarcomeric actin labeling of myocyte cytoplasm (red fluorescence). AT II positive sites and laminin are shown by yellow fluorescence. Confocal microscopy, $\times 900$.

diabetes, $p=0.37$ versus control). In summary, diabetes enhanced the synthesis of AT II in myocytes, and losartan inhibited the formation of this peptide, thus preventing ligand binding to $A T_{1}$ receptors and the activation of cell death.

\section{Discussion}

The results of the current study indicate that STZinduced diabetes led to a cardiac myopathy characterized by myocyte loss and modest reactive hypertrophy of the remaining cells in the absence of collagen accumulation in the ventricular wall. Myocyte death by apoptosis was the exclusive form of cell dropout in the acute, subacute, and established phases of the disease. Myocyte necrosis was absent throughout. The sudden increase in glucose level that occurred shortly after STZ administration was coupled with the greatest degree of cell death. Hyperglycemia remained constant with time, but the extent of myocyte apoptosis decreased progressively over 4 weeks of observation. The metabolic defects of diabetes acutely upregulated the local RAS, which resulted in an increased formation of AT II in myocytes. Pretreatment with losartan attenuated the synthesis of AT II 
A Ang II-Labeled Myocytes

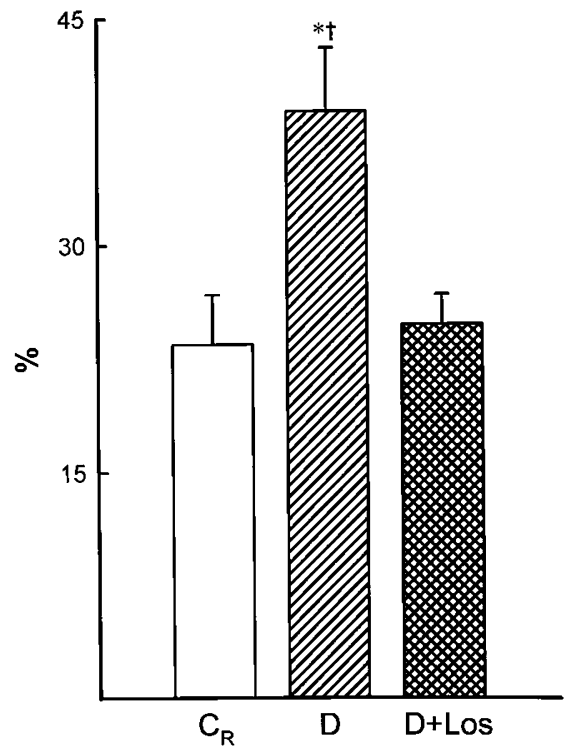

C

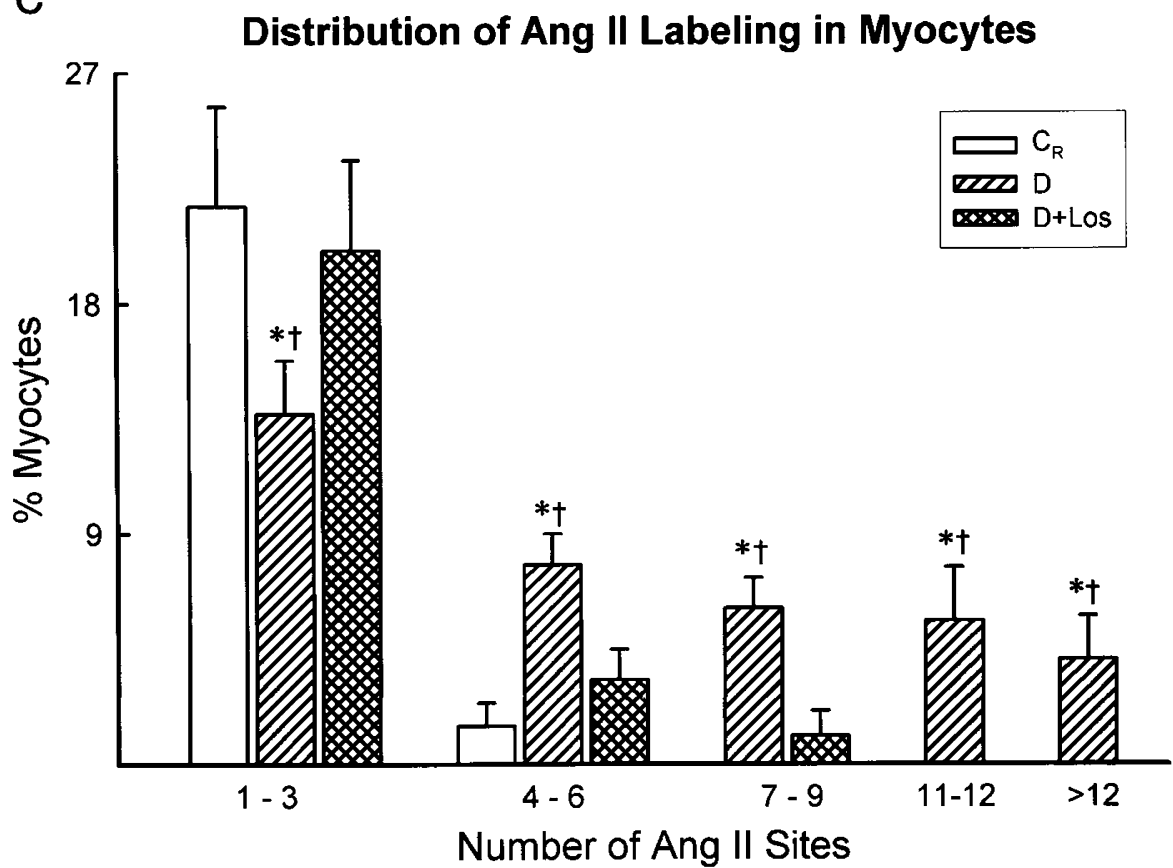

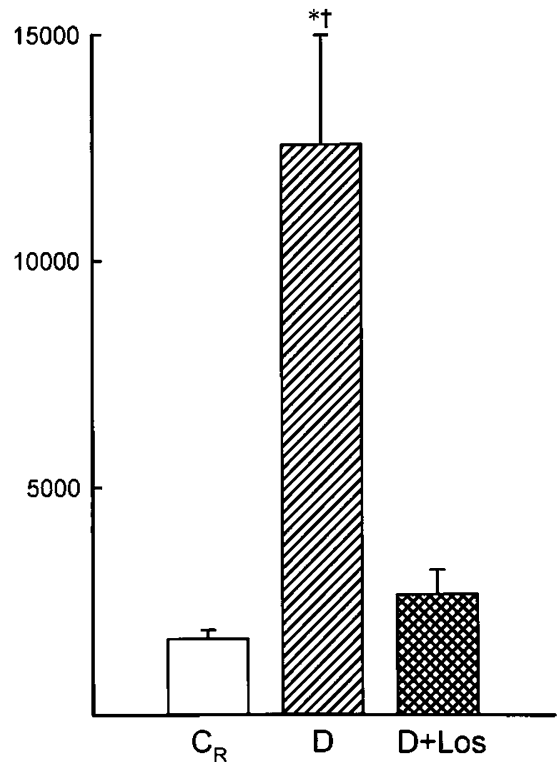

Ang II Sites $/ \mathrm{mm}^{2}$ Myocytes

Figure 8.

The effect of 3 days of diabetes and treatment with losartan on the percentage of myocytes labeled by AT II (A), the number of AT II positive sites per square millimeter of myocytes (B), and the distribution of AT II sites in myocytes $(C)$. Results are mean $\pm S D$ *Indicates a difference from control rats on a restricted diet $\left(C_{R}\right)$, ${ }^{\text {indicates }}$ a difference from diabetic rats treated with losartan $(D+L O S)$. $D$, diabetic rats. In panel $C$, the open bars correspond to control rats on a restricted diet, the hatched bars to diabetic rats, and the crosshatched bars to diabetic rats treated with losartan. $\mathrm{C}_{\mathrm{R}}: n=5, \mathrm{D}: n=6, \mathrm{D}+\mathrm{Los}: n=6$ in panels $\mathrm{A}, \mathrm{B}$, and $\mathrm{C}$.

and prevented the activation of myocyte death in rats with diabetes. The $\mathrm{AT}_{1}$ receptor blocker had no effect on hyperglycemia. In this model, diabetic cardiomyopathy may be viewed as an AT II-dependent process in which hyperglycemia plays an initial critical role.

\section{Diabetes and Myocyte Death}

Heart failure of ischemic or nonischemic origin is more frequent and severe in patients with diabetes (Ro- 
cle at 4 weeks after STZ administration, and this was associated with a $14 \%$ increase in volume of the surviving cells. Both phenomena decrease the reserve of the myocardium to sustain increases in mechanical load generated by myocardial infarction, systemic hypertension, or their combination. Diabetic cardiomyopathy resembles the aged heart in men, in which tissue damage is not apparent in spite of an agedependent loss of myocytes and reactive hypertrophy of the viable cells (Olivetti et al, 1991, 1995). Similar findings have been obtained in aging Sprague-Dawley rats (Anversa et al, 1986). Heart failure is a disease that affects individuals in the sixth decade of life and older (Cohn et al, 1997). Diabetes may accelerate the effects of aging (Garcia et al, 1974) and the effects of pathologic states on the onset of cardiac dysfunction and its progression to terminal failure.

Myocyte death, which was higher at 3 days than at 10 and 28 days, was mediated exclusively by apoptosis. The lowest degree of myocyte death was observed at 28 days. Myocyte necrosis was not detected. These observations are consistent with the involvement of humoral factors in the activation of the suicide program of myocytes, which diminishes the influence of vascular abnormalities and the induction of cell necrosis. The prominent role of apoptosis was confirmed by the lack of changes in the volume composition of the myocardium and by the absence of foci of replacement fibrosis in the ventricular wall. Widening of the extracellular compartment between myocytes and interstitial deposition of collagen were not found. These modifications typically occur as a result of myocyte necrosis that involves either multiple large clusters of cells or one to three myocytes in a diffuse, scattered manner (Li et al, 1999; Anversa et al, 1998). Interstitial fibrosis may also develop by connective tissue cell proliferation that is independent of cell necrosis (Weber and Brilla, 1991). Conversely, apoptosis does not stimulate reparative processes with scar formation and collagen accumulation (Haunstetter and Izumo, 1998). Nuclear fragmentation and cell shrinkage lead to apoptotic bodies that are engulfed by the surrounding cells. The proportion of tissue components remains essentially constant (Gerschenson and Rotello, 1992; Anversa and Kajstura, 1998).

\section{Diabetes and Myocyte RAS}

ACE inhibition attenuates the detrimental impact of diabetes on the kidney (Zutz et al, 1986; Lewis et al, 1993) and the heart in humans (Zuanetti et al, 1997). Experimental data have shown comparable findings (Malhotra et al, 1997). This study provides the first documentation that acutely after STZ administration there is an upregulation of the local RAS in the heart. The expression of Aogen, renin, and $A T_{1}$ receptor in myocytes was enhanced at 3 days, and this response was coupled with an increased synthesis of AT II. ACE and $\mathrm{AT}_{2}$ receptor were apparent, but their quantities did not change with diabetes. The generation of AT II in myocytes decreased at 10 days, and this change was paralleled by a reduction in myocyte apoptosis in the ventricular wall. Blockage of the $\mathrm{AT}_{1}$ receptor and its effector pathway by losartan at the peak of apoptosis prevented cell death and reduced the formation of AT II in myocytes without affecting hyperglycemia.

AT II transmits death signals to myocytes through ligand binding to $\mathrm{AT}_{1}$ receptors (Kajstura et al, 1997; Pierzchalski et al, 1997; Leri et al, 1998; Leri et al, 1999a), and distal events include a form of DNA damage consisting of staggered ends with single base 3' overhang (Leri et al, 1998). This has been confirmed in this study by the detection of double-strand DNA cleavage with in situ ligation of a hairpin oligonucleotide probe that possesses single base $3^{\prime}$ overhang (Didenko et al, 1998). TdT labeling also recognizes this type of DNA fragmentation (Didenko and Hornsby, 1996), and comparable results were obtained with the two probes. AT II stimulates myocyte hypertrophy (Liu et al, 1998) via $A T_{1}$, and cellular enlargement with diabetes may be an AT II-mediated response. The dual actions of AT II leave unanswered the question of why certain myocytes respond to the hormone by triggering the endogenous cell death pathway and others respond by undergoing cellular hypertrophy. Understanding the decreased synthesis of AT II in myocytes during the course of diabetes is also difficult.

These issues were not investigated in this study, but there is a possibility that advanced hyperglycemia and increased cytoplasmic glucose concentration may lead to glycosylation of the C-terminal of the tumor suppressor p53 (Shaw et al, 1996). p53 activation may result in its translocation to the nucleus, where it initiates transcription of a number of p53-dependent genes including Aogen and $\mathrm{AT}_{1}$ receptor (Pierzchalski et al, 1997; Leri et al, 1998; Leri et al, 1999a). Upregulation of Aogen increases the synthesis of AT II (Baker et al, 1992), the local release of which may trigger cell death in susceptible myocytes (Li et al, 1997a; Tanimura et al, 1999) and promote hypertrophy in responding cells (Li et al, 1997a; Liu et al, 1998). Insulin-like growth factor (IGF)-1 has the ability to oppose p53 stimulation through the expression of Mdm2 and the formation of inactive Mdm2-p53 complexes (Leri et al, 1999a, 1999b). Inhibition of p53 function by IGF-1 attenuates the myocyte RAS and cell death in vitro (Leri et al, 1999a) and in vivo (Li et al, 1997b; Li et al, 1999; Leri et al, 1999b). The IGF-1 system is enhanced locally in the kidney in those with diabetes (Oemar et al, 1991), and a similar adaptation may occur in the myocardium, which decreases the myocyte RAS, apoptosis, and growth.

\section{Diabetes and Cardiac Function}

Loss of myocytes in a scattered and diffuse manner has a greater detrimental effect on cardiac function than a segmental loss of cells (Anversa et al, 1992). The first condition is encountered in dilated cardiomyopathy and in nonocclusive coronary artery constriction, whereas the second is found after occlusion of a major epicardial coronary artery and acute myocardial infarction (Anversa et al, 1998). Cell death, which is also distributed nonhomogeneously in the surviving 
myocardium after infarction, has significant consequences on the progression of ischemic myopathy to end-stage cardiac failure (Beltrami et al, 1994). Experimental results strongly support this contention (Cheng et al, 1996a). In this study, however, diabetes was characterized by a $30 \%$ loss of myocytes with modest alterations in ventricular hemodynamics that were almost identical to those seen in pair-fed animals in which cell death did not occur. These observations were unexpected and surprising.

With coronary stenosis in rats, a $20 \%$ loss of myocytes across the ventricular wall results in severe decompensation (Anversa et al, 1992) that mimicks the impact of a $50 \%$ infarct acutely and chronically (Pfeffer and Braunwald, 1990). Two explanations may be offered for the apparent contrasting observations of this study. Myocyte death in diabetes took place in the absence of reductions in luminal diameter of the coronary artery and blood supply to the myocardium, and myocyte death occurred by apoptosis, excluding myocardial scarring and collagen accumulation. However, other factors such as body weight changes and the duration of diabetes may have influenced these results.

\section{Limitations of the Study and Conclusions}

This study has several limitations. The relationship between ventricular performance and ongoing myocyte death and accumulated cell loss was analyzed only at 4 weeks after the induction of diabetes. Longer intervals must be examined to establish whether chronic myocyte loss leads to cardiac dysfunction in this model. Additionally, the IGF-1-IGF-1 receptor system has been implicated in the downregulation of the myocyte RAS in diabetics, but this possibility remains speculative. Finally, activation of p53 function has been proposed as a critical early event in AT II formation and the initiation of apoptosis. At present, these are working hypotheses. Although these limitations must be considered when the accumulated results are interpreted, the current observations point to the myocyte RAS as a major determinant of the development of diabetic cardiomyopathy.

\section{Materials and Methods}

\section{Animals}

Diabetes was induced in 59 male Sprague Dawley rats (Charles River Breeding Company, North Wilmington, Massachusetts) that weighed 250-300 gm by intravenous injection of $60 \mathrm{mg} / \mathrm{kg}$ body weight of STZ (Sigma Chemical Company, St. Louis, Missouri) that had been dissolved in 20 mmole sodium citrate saline buffer. Thirty-seven untreated animals were used as controls. When the rats had been anesthetized with ether, a drop of blood was obtained by puncture of the tail vein, and blood glucose was determined (Accu-Check Instant test; Boehringer Mannheim, Indianapolis, Indiana) at 24 hours and at 3, 10, and 28 days after STZ administration. Control rats were similarly examined. In the diabetic group, only animals with a nonfasting blood glucose greater than $19.4 \mathrm{mmole} / \mathrm{L}$ were included in the study; 6 of the initial 59 rats were excluded. Sixteen of the 53 diabetic rats were pretreated with losartan for 24 hours before the induction of diabetes, and the $\mathrm{AT}_{1}$ blocker was continued until the animals were killed. Losartan was given at 0.25 $\mathrm{gm} / \mathrm{L}$ in the drinking water; this corresponded to a daily dose of $46 \mathrm{mg} / \mathrm{kg}$ body weight. Because a significant loss in body weight occurs as a result of diabetes, control rats were subdivided in two groups: 21 that were maintained on free food and water and 16 that were fed a restricted diet. The amount of food consumed and body weight were measured daily.

Different rats were studied at 3,10 , and 28 days as follows: STZ-treated rats $(n=19)$, STZ and losartan treated rats $(n=16)$, and untreated rats on a restricted diet $(n=14)$ were included at 3 days. The collected parameters were ventricular function, myocyte death, AT II concentration and distribution in myocytes, expression of myocyte RAS, and effects of $A T_{1}$ blocker on myocyte death. STZ-treated rats $(n=8)$ and untreated rats on a restricted diet $(n=4)$ were examined at 10 days to evaluate cardiac function, myocyte death, and AT II labeling in myocytes. STZtreated rats $(n=10)$, untreated rats $(n=15)$, and untreated rats on a restricted diet $(n=8)$ were analyzed at 28 days to determine cardiac function, myocyte death, the number of ventricular myocytes, and myocyte cell volume.

\section{Ventricular Hemodynamics}

When the rats had been anesthetized with chloral hydrate $(300 \mathrm{mg} / \mathrm{kg} \mathrm{ip})$, the right carotid artery was cannulated with a microtip pressure transducer catheter (Millar SPR-249, Houston, Texas) connected to an electrostatic chart recorder (Gould ES 2000, Cleveland, Ohio). After arterial blood pressure had been monitored, the catheter was advanced into the left ventricle for evaluation of the left ventricular pressures and + and $-\mathrm{dP} / \mathrm{dt}$. A second catheter (Millar SPR$595)$ with a $120^{\circ}$ curved tip was inserted into the right jugular vein and was advanced into the right ventricle to measure the central venous pressure, ventricular pressures, and + and -dP/dt (Kajstura et al, 1994; Cheng et al, 1996b).

\section{Ongoing Myocyte Death}

Animals were killed by arresting the heart in diastole by intravenous injection of 1 mole $\mathrm{KCl}$. For the analysis of cell death at 3 and 10 days, the heart was excised. The left ventricle inclusive of the septum and the right ventricle were dissected, and their weights were recorded. The left ventricle was then cut perpendicular to its longitudinal axis halfway between the base and the apex, and these two portions were fixed in phosphate-buffered $4 \%$ formaldehyde and were frozen in OCT compound. Frozen sections were used for AT II localization and as fixed samples for the assessment of myocyte death in paraffin sections. Myocyte apoptosis was determined by two methods: TdT as- 
say (Leri et al, 1998; Li et al, 1999) and in situ ligation of the hairpin DNA probe with single base $3^{\prime}$ overhang (Leri et al, 1998; Li et al, 1999; Didenko and Hornsby, 1996; Didenko et al, 1998). Myocyte necrosis was evaluated by in situ ligation of a Pfu polymerase generated probe (Li et al, 1999; Didenko and Hornsby, 1996) and by a hairpin probe with a blunt DNA end (Didenko et al, 1998). These methods were also used at 28 days in hearts in which the total number of myocytes and myocyte cell volume were measured; these required perfusion fixation and a complex morphometric approach (see below).

\section{Myocyte Death Assays}

TdT assay was performed by incubating sections with 5 units of TdT, 2.5 mmole $\mathrm{CoCl}_{2}, 0.2$ mole potassium cacodylate, 25 mmole Tris- $\mathrm{HCl}, 0.25 \%$ bovine serum albumin (BSA), and $0.5 \mathrm{nmol}$ biotinylated 2'deoxyuridine-5'-triphosphate (biotin-16-d-UTP). The staining solution consisted of $5 \mu \mathrm{g} / \mathrm{ml}$ of fluorescein isothiocyanate (FITC)-labeled Extravidin (Sigma), $4 \mathrm{x}$ concentrated saline-sodium citrate buffer, $0.1 \%$ Triton $\mathrm{X}-100$, and $5 \%$ nonfat dry milk.

In situ ligation of $P f u$ polymerase generated probe was performed as follows: Pfu probe was prepared with primers 5'-GTGGCCTGCCCAAGCTCTACCT-3' and 5'GGCTGGTCTGCCGCCGTITCGACCCTG-3' complementary to pBluescript-bSDI1 plasmid (Li et al, 1999; Didenko and Hornsby, 1996). Polymerase chain reaction (PCR) was performed as previously described (Leri et al, 1998). After the mixture was heated to $80^{\circ} \mathrm{C}, 5 \mathrm{U} P f u$ polymerase was added. Gel electrophoresis documented a single PCR product that was purified with a PCR purification kit (Qiagen,Valencia, California). Digoxigenin-labeled probes were ligated to DNA by means of T4 ligase (Boehringer Mannheim, Indianapolis, Indiana). Sections were treated with proteinase $\mathrm{K}$ and 50 $\mu \mathrm{g} / \mathrm{ml}$ phosphate-buffered saline (PBS). A mixture of 50 mmole Tris- $\mathrm{HCl}$ (pH 7.8), 10 mmole $\mathrm{MgCl}_{2}, 10$ mmole dithiothreitol, 1 mmole adenosine triphosphate (ATP), 25 $\mu \mathrm{g} / \mathrm{ml}$ bovine serum albumin (BSA), 15\% polyethylene glycol, $1 \mu \mathrm{g} / \mathrm{ml}$ probe, and $25 \mathrm{U} / \mathrm{ml}$ T4 ligase was applied for 4 hours. Samples were washed at $70^{\circ} \mathrm{C}$, were incubated with antidigoxigenin mouse monoclonal antibody, and were exposed to FITC-labeled goat antimouse immunoglobulin G (lgG) (Li et al, 1999).

In situ ligation of hairpin oligonucleotide with single base overhang and with blunt DNA end was performed as follows: Sections were incubated with protease $\mathrm{K}, 25 \mu \mathrm{g} / \mathrm{ml}$ and were treated with a solution containing 50 mmole Tris- $\mathrm{HCl}, \mathrm{pH}$ 7.8; 10 mmole $\mathrm{MgCl}_{2} ; 10$ mmole dithiothreitol; 1 mmole ATP; $15 \%$ polyethylene glycol 8000, $1 \mathrm{U} / \mu \mathrm{l}$ T4 ligase; and 35 $\mathrm{ng} / \mu \mathrm{l}$ hairpin probe (Synthetic Genetics Corp., San Diego, California) with single base $3^{\prime}$ overhang or blunt DNA end (Didenko et al, 1998). Subsequently, samples were exposed to FITC-Extravidin, $5 \mu \mathrm{g} / \mathrm{ml}$ in bicarbonate buffer. Detection of myocyte cytoplasm was obtained by $\alpha$-sarcomeric actin labeling; nuclei were stained by propidium iodide (Leri et al, 1998; Li et al, 1999). A Noran Oz High Speed laser scanning confocal microscope was used.

\section{AT II Labeling}

Frozen tissue sections were fixed in 3.7\% formaldehyde and were incubated with AT II antiserum (Peninsula Laboratories Inc, Belmont, California) and with FITC-labeled goat antirabbit IgG. Specificity was determined by preabsorbtion of $10 \mu \mathrm{l}$ of antibody with $0.05 \mathrm{mg}$ of antigen. Nonimmune rabbit serum was used as an additional control. Sections were stained with laminin antibody (Sigma) to define myocyte boundary. Cytoplasm was identified by $\alpha$-sarcomeric actin. Sections were examined by confocal microscopy. Myocytes containing AT II positive sites and the number of sites per myocyte profile were evaluated (Leri et al, 1999b).

\section{Perfusion Fixation}

When the rats had been anesthetized, the abdominal aorta was cannulated with a PE-200 catheter, the heart was arrested in diastole, the thorax was opened, perfusion with buffer was started, and the atrium was cut to allow drainage (Kajstura et al, 1994; Li et al, 1999). The myocardium was perfused first with buffer and then with $4 \%$ formaldehyde. The heart was excised, and cardiac weights were measured. Five slices of the left ventricle from base to apex were embedded in paraffin.

\section{Myocyte Size and Number}

In each left ventricle, sections were stained with $\mathrm{H}$ \& $\mathrm{E}$. Morphometric sampling at $\times 1250$ consisted of counting the number of myocyte nuclear profiles, $N(n)$, in a measured area, $A$, of tissue section in which cardiac muscle cells were cut transversely. A square tissue area of $9604 \mu \mathrm{m}^{2}$ was delineated in the microscopic field by an ocular reticle containing 42 sampling points. Twenty-five fields were counted in the inner and outer layers of each left ventricle to determine the number of nuclear profiles per unit area of myocardium, $\mathrm{N}(\mathrm{n})_{\mathrm{A}}$, and the volume fraction of myocytes, $\mathrm{V}(\mathrm{m})_{\mathrm{V}}$. Nuclear length, $\mathrm{D}(\mathrm{n})$, was obtained from 50 measurements each in longitudinally oriented myocytes viewed at $\times 1250$ with a micrometer accurate to $0.5 \mu \mathrm{m}$. From $\mathrm{N}(\mathrm{n})_{\mathrm{A}}$ and $\mathrm{D}(\mathrm{n})$, the number of myocyte nuclei per unit volume of myocardium, $N(n)_{V}$, was computed (Kajstura et al, 1994; Anversa et al, 1992):

$$
N(n)_{v}=N(n)_{A} / D(n)
$$

Myocyte cell volume per nucleus in the inner and outer layers of the wall of each left ventricle, $V(m)_{n}$, was calculated from the volume fraction of myocytes in the tissue, $\mathrm{V}(\mathrm{m})_{\mathrm{V}}$, divided by the number of myocyte nuclei per unit volume of myocardium, $N(n)_{V}$ :

$$
\mathrm{V}(\mathrm{m})_{\mathrm{n}}=\mathrm{V}(\mathrm{m})_{\mathrm{v}} / \mathrm{N}(\mathrm{n})_{\mathrm{v}}
$$

The total number of myocyte nuclei in each ventricle, $\mathrm{N}(\mathrm{n})_{\mathrm{T}}$, was derived from the product of the number per 
unit volume, $\mathrm{N}(\mathrm{n})_{\mathrm{V}}$, and the total left ventricular volume, $V_{\mathrm{T}}$. The latter was evaluated by dividing ventricular weight by the specific gravity of muscle tissue (Kajstura et al, 1994; Anversa et al, 1992):

$$
\mathrm{N}(\mathrm{n})_{\mathrm{T}}=\mathrm{N}(\mathrm{n})_{\mathrm{V}} \cdot \mathrm{V}_{\mathrm{T}}
$$

\section{Myocyte Isolation}

The cell isolation procedure extensively used in our laboratory (Kajstura et al, 1994, 1997; Cheng et al 1996b; Liu et al, 1998; Leri et al, 1998) consisted of the following three main steps. Low calcium perfusion involved blood washout in the presence of ethyleneglycol-bis $(\beta-$ aminoethyl ether)- $N, N, N,{ }^{\prime}, N$ - and perfusion of the myocardium with collagenase (Type I, Worthington Biochemical Company, Freehold, New Jersey). Mechanical tissue dissociation was performed after the heart was removed; the left ventricle was cut into small pieces and was shaken in resuspension medium. Separation of intact cells was accomplished as follows: Intact cells were enriched by centrifugation through Percoll (Sigma) and were then recovered from the pellet and were used to determine Western blot and AT II levels. The average number of myocytes obtained from the left ventricle was $6-7 \times 10^{6}$. The extent of nonmyocytes was determined by counting 1000 cells. Contamination from nonmyocytes was $1 \%$ to $2 \%$ in all animal groups (Kajstura et al, 1994, 1997; Cheng et al 1996b; Liu et al, 1998; Leri et al, 1998).

\section{Western Blot}

For immunoblotting of Aogen, renin, $\mathrm{ACE}, \mathrm{AT}_{1}$, and $A T_{2}$, myocytes were lysed with $250 \mu$ l of lysis buffer (50 mmole Tris- $\mathrm{HCl}, \mathrm{pH} 7.5 ; 5$ mmole ethylenediaminetetraacetate; 250 mmole $\mathrm{NaCl} 0.1 \%$ Triton X-100) containing the protease inhibitors phenylmethylsulfonyl fluoride, 2 mmole; aprotinin, $1 \mu \mathrm{g} / \mathrm{ml}$; dithiothreitol, 5 mmole; and $\mathrm{Na}_{3} \mathrm{VO}_{4}, 1 \mathrm{mmole}$. Proteins, $50 \mu \mathrm{g}$, were separated by $10 \%$ to $12 \%$ sodium dodecyl sulfatepolyacrylamide gel electrophoresis, were transferred onto nitrocellulose filters, and were exposed to mouse monoclonal antirat Aogen (Swant, Bellinzona, Switzerland), mouse monoclonal antirat renin (Swant), mouse monoclonal antihuman ACE (Chemicon, Temecula, California), rabbit polyclonal antirat $\mathrm{AT}_{1}$ receptor (Chemicon), and goat antihuman $\mathrm{AT}_{2}$ receptor (Santa Cruz, Santa Cruz, California) at a concentration of 1 $\mu \mathrm{g} / \mathrm{ml}$ in Tris-buffered saline/Tween 20 (10 mmole Tris- $\mathrm{HCl}, 0.15$ mole $\mathrm{NaCl}, 0.5 \%$ Tween 20). Bound antibodies were detected by peroxidase conjugated antimouse, antirabbit, or antigoat IgG (Santa Cruz) (Leri et al, 1998, 1999a, 1999b). Aogen was detected as a 56-58 kd band, renin as a 36-37 kd, glycosylated ACE as a $170 \mathrm{kd}$, nonglycosylated ACE as a $134 \mathrm{kd}$, $\mathrm{AT}_{1}$ as a $41 \mathrm{kd}$, and $\mathrm{AT}_{2}$ as a $44 \mathrm{kd}$.

\section{AT II Concentration}

Myocytes were suspended in 1 mole acetic acid (Meng et al, 1993) and were homogenized and centrifuged at $15,000 \mathrm{rpm}$ for 30 minutes at $4^{\circ} \mathrm{C}$. Superna- tants were dried, reconstituted with $0.1 \%$ trifluoroacetic acid, and purified by means of a C18 Sep-Pak column (Waters Associates, Milford, Massachusetts). This fraction was eluted from the column with $30 \%$ acetonitrile in $0.1 \%$ trifluoroacetic acid, $5 \mathrm{ml}$, and was dried and dissolved in $0.25 \mathrm{ml}$ Tris-buffered saline/ Tween 20 solution. Samples of $50 \mu$ l were analyzed in a microtiter plate via anti-AT II antibody (Peninsula) and a tracer, biotinylated AT II. The plate was washed 5 times with Tris-buffered saline/Tween 20 and was treated with streptavidin horseradish peroxidase. Color reaction was developed with $100 \mu$ l of tetramethylbenzidine substrate and was terminated by $2 \mathrm{~N}$ $\mathrm{HCl}$. Absorbance was recorded at $450 \mathrm{~nm}$, and the concentration was calculated from the standard curve generated each time for AT II (Leri et al, 1999a, 1999b).

\section{Data Collection and Analysis}

Results are presented as mean $\pm \mathrm{SD}$. The significance, $p<0.05$, between two values was determined by Student's $t$-test. Significance in multiple comparisons was determined by analysis of ANOVA and the Bonferroni method (Wallenstein et al, 1980). Measurements presented were not obtained in all rats; $n$ values for each parameter are listed in the text or in the legend to each figure.

\section{References}

Anversa P, Hiler B, Ricci R, Guideri G, and Olivetti G (1986). Myocyte cell loss and myocyte hypertrophy in the aging rat heart. J Am Coll Cardiol 8:1441-1448.

Anversa P and Kajstura J (1998). Myocyte cell death in the diseased heart. Circ Res 82:1231-1233.

Anversa P, Leri A, Beltrami CA, Guerra S, and Kajstura J (1998). Myocyte death and growth in the failing heart. Lab Invest 78:676-786.

Anversa P, Zhang X, Li P, and Capasso JM (1992). Chronic coronary artery constriction leads to moderate myocyte loss and left ventricular dysfunction and failure in rats. $J$ Clin Invest 89:618-629.

Baker KM, Booz GW, and Dostal DE (1992). Cardiac actions of angiotensin II: Role of an intracardiac renin-angiotensin system. Annu Rev Physiol 54:227-241.

Bell DSH (1995). Diabetic cardiomyopathy: A unique entity or a complication of coronary artery disease? Diabetes Care 18:708-714.

Beltrami CA, Finato N, Rocco M, Feruglio GA, Puricelli C, Cigola E, Quaini F, Sonnenblick EH, Olivetti G, and Anversa P (1994). Structural basis of end-stage failure in ischemic cardiomyopathy in humans. Circulation 89:151-163.

Cheng W, Kajstura J, Nitahara JA, Li B, Reiss K, Liu Y, Clark WA, Krajewski S, Reed JC, Olivetti G, and Anversa P. (1996a). Programmed myocyte cell death affects the viable myocardium after infarction in rats. Exp Cell Res 226:316-327.

Cheng W, Reiss K, Li P, Chun MJ, Kajstura J, Olivetti G, and Anversa P. (1996b). Aging does not affect the activation of the myocyte insulin-like growth factor-1 autocrine system after infarction and ventricular failure in Fischer 344 rats. Circ Res 78:536-546. 
Cohn JN, Bristow MR, Chien KR, Colucci WS, Frazier $\mathrm{OH}$, Leinwand LA, Lorell BH, Moss AJ, Sonnenblick EH, Walsh RA, Mockrin SC, and Reinlib L (1997). Report of the National Heart, Lung, and Blood Institute special emphasis panel on heart failure research. Circulation 95:766-770.

Didenko VV and Hornsby PJ (1996). Presence of doublestrand breaks with single-base $3^{\prime}$ overhangs in cells undergoing apoptosis but not necrosis. J Cell Biol 135:1369-1376.

Didenko VV, Tunstead JR, and Hornsby PJ (1998). Biotinlabeled hairpin oligonucleotides. Probes to detect doublestrand breaks in DNA in apoptotic cells. Am J Pathol 152: 897-902.

Fein FS and Sonnenblick EH (1985). Diabetic cardiomyopathy. Prog Cardiovasc Dis 27:255-270.

Fuller JH, Shipley MJ, Rose G, Jarret RJ, and Keen H (1980). Coronary heart disease risk and impaired glucose tolerance: The Whitehall Study. Lancet i:1373-1376.

Garcia MJ, McNamara PM, Gordon T, and Kannell WB (1974). Morbidity and mortality in diabetics in the Framingham population: Sixteen-year follow-up study. Diabetes 23: 105-111.

Gerschenson LE and Rotello RJ (1992). Apoptosis: A different type of cell death. FASEB J 6:2450-2455.

Hardin NJ (1996). The myocardial and vascular pathology of diabetic cardiomyopathy. Coron Artery Dis 7:99-108.

Haunstetter A and Izumo S (1998). Apoptosis: Basic mechanisms and implications for cardiovascular disease. Circ Res 82:1111-1129.

Kajstura J, Cigola E, Malhotra A, Li P, Cheng W, Meggs LG, and Anversa P (1997). Angiotensin II induces apoptosis of adult ventricular myocytes in vitro. J Mol Cell Cardiol 29:859870.

Kajstura J, Zhang X, Reiss K, Szoke E, Li P, Lagrasta C, Cheng W, Darzynkiewicz Z, Olivetti G, and Anversa P (1994). Myocyte cellular hyperplasia and myocyte cellular hypertrophy contribute to chronic ventricular remodeling in coronary artery narrowing-induced cardiomyopathy in rats. Circ Res 74:383-400.

Kannel WB and McGee DL (1979). Diabetes and cardiovascular disease: The Framingham study. JAMA 241:20352038.

Leri A, Claudio PP, Li Q, Wang X, Reiss K, Wang S, Malhotra A, Kajstura J, and Anversa P (1998). Stretch-mediated release of angiotensin II induces myocyte apoptosis by activating $p 53$ that enhances the local renin-angiotensin system and decreases the $\mathrm{Bcl}-2$-to-Bax protein ratio in the cell. $\mathrm{J}$ Clin Invest 101:1326-1342.

Leri A, Liu Y, Claudio PP, Kajstura J, Wang X, Wang S, Kang P, Malhotra A, and Anversa P (1999a). Insulin-like growth factor-1 induces Mdm2 and down-regulates p53, attenuating the myocyte renin-angiotensin system and stretch-mediated apoptosis. Am J Pathol 154:567-580.

Leri A, Liu Y, Wang X, Kajstura J, Malhotra A, Meggs LG, and Anversa $P$ (1999b). Overexpression of insulin-like growth factor- 1 attenuates the myocyte renin-angiotensin system in transgenic mice. Circ Res 84:752-762.

Lewis EJ, Hunsicker LG, Bain RP, and Rohde RD (1993). The effect of angiotensin-coverting enzyme inhibition on diabetic nephropathy. N Engl J Med 329:1456-1462.
Li Z, Bing OHL, Long X, Robinson KG, and Lakatta EG (1997a). Increased cardiomyocyte apoptosis during the transition of heart failure in the spontaneously hypertensive rat. Am J Physiol 272:H2313-H2319.

Li Q, Li B, Wang X, Leri A, Jana KP, Liu Y, Kajstura J, Baserga $R$, and Anversa $P$ (1997b). Overexpression of insulin-like growth factor- 1 in mice protects from myocyte death after infarction, attenuating ventricular dilation, wall stress, and cardiac hypertrophy. J Clin Invest 100:1991-1999.

Li B, Setoguchi M, Wang X, Andreoli AM, Leri A, Malhotra A, Kajstura J, and Anversa P (1999). Insulin-like growth factor-1 attenuates the detrimental impact of nonocclusive coronary artery constriction on the heart. Circ Res 84:1007-1019.

Liu Y, Leri A, Li B, Wang X, Cheng W, Kajstura J, and Anversa $P$ (1998). Angiotensin II stimulation in vitro induces hypertrophy of normal and postinfarcted ventricular myocytes. Circ Res 82:1145-1159.

Malhotra A, Penpargkul S, Fein FS, Sonnenblick EH, and Scheuer J (1981). The effect of streptozotocin induced diabetes in rats on cardiac contractile proteins. Circ Res 49: 1243-1250.

Malhotra A, Reich D, Reich D, Nakouzi A, Sanghi V, Geenen DL, and Buttrick PM (1997). Experimental diabetes is associated with functional activation of protein kinase $\mathrm{C} \epsilon$ and phosphorylation of troponin I in the heart, which are prevented by angiotensin II receptor blockade. Circ Res 81: 1027-1033.

Meng QC, Durand J, Chen YF, and Oparil S (1993). Simplified method for quantitation of angiotensin peptides in tissue. J Chromatogr 614:19-25.

Oemar BS, Foellmer HG, Hodgdon-Anandant L, and Rosenzweig SA (1991). Regulation of insulin-like growth factor I receptors in diabetic mesangial cells. J Biol Chem 266:23692373.

Olivetti G, Giordano G, Corradi D, Melissari M, Lagrasta C, Gambert SR, and Anversa P (1995). Gender differences and aging: Effects on the human heart. J Am Coll Cardiol 26: 1068-1079.

Olivetti G, Melissari M, Capasso JM, and Anversa P (1991). Cardiomyopathy of the aging human heart: Myocyte loss and reactive cellular hypertrophy. Circ Res 68:1560-1568.

Pfeffer MA and Braunwald E (1990). Ventricular remodeling after myocardial infarction. Circulation 81:1161-1172.

Pierce GN and Dhalla NS (1981). Cardiac myofibrillar ATPase activity in diabetic rats. J Mol Cell Cardiol 13:1063-1069.

Pierzchalski P, Reiss K, Cheng W, Cirielli C, Kajstura J, Nitahara JA, Rizk M, Capogrossi MC, and Anversa P (1997). p53 induces myocyte apoptosis via the activation of the renin-angiotensin system. Exp Cell Res 234:57-65.

Rockman HA, Wachhorst SP, Mao L, and Ross J (1994). ANG II receptor blockade prevents ventricular hypertrophy and ANF gene expression with pressure overload in mice. Am J Physiol 266:H2468-H2475.

Rodrigues B, Cam MC, and McNeill JH (1998). Metabolic disturbances in diabetic cardiomyopathy. Mol Cell Biochem 180:53-57.

Rodrigues B and McNeill JH (1992). The diabetic heart: Metabolic causes for the development of a cardiomyopathy. Cardiovasc Res 26:913-922. 
Shaw P, Freeman J, Bovey R, and Iggo R (1996). Regulation of specific DNA binding by p53: Evidence for a role for O-glycosylation and charged residues at the carboxyterminus. Oncogene 12:921-930.

Tanimura M, Sharov VG, Shimoyama H, Mishima T, Levine TB, Goldstein S, and Sabbah HN (1999). Effects of AT $_{1-}$ receptor blockade on progression of left ventricular dysfunction in dogs with heart failure. Am J Physiol 276:H1385H1392.

Wallenstein S, Zucker CL, and Fleiss JL (1980). Some statistical methods useful in circulation research. Circ Res 47:1-9.
Weber KT and Brilla CG (1991). Pathological hypertrophy and cardiac interstitium. Circulation 83:1849-1865.

Zuanetti G, Latini R, Maggioni AP, Franzosi MG, Santoro L, and Tognoni G (1997). Effect of the ACE inhibitor lisinopril on mortality in diabetic patients with acute myocardial infarction. Circulation 96:4239-4245.

Zutz R, Dunn BR, Meyer TW, Anderson S, Renneker H, and Brenner BM (1986). Prevention of diabetic glomerulopathy by pharmacological amelioration of capillary hypertension. J Clin Invest 77:1925-1930. 